\author{
Jurnal Segara JURNAL SEGARA \\ http://ejournal-balitbang.kkp.go.id/index.php/segara \\ ISSN : 1907-0659 \\ e-ISSN : 2461-1166 \\ Nomor Akreditasi: 766/AU3/P2MI-LIPI/10/2016
}

\title{
CHARACTERISTIC OF SALEH BAY COASTLINE
} KARAKTERISTIK PESISIR TELUK SALEH

\author{
Yulius $^{1)}$, M. Ramdhan ${ }^{1)} \&$ Ardiansyah $^{2)}$ \\ ${ }^{1)}$ Marine Research Center, Republic Indonesian Ministry of Marine Affairs \& Fisheries Jakarta \\ ${ }^{2}$ Department of Geography, Faculty of Mathematics and Natural Sciences, \\ Universitas Indonesia, Depok \\ Received: 17 May 2016; Revised: 19 Juli 2018; Accepted: 31 August 2018
}

\begin{abstract}
Saleh Bay is a large bay in Sumbawa island of the NTB Province. The bay includes an area of 1910 square kms with depths of 0 to 324 meters. The coastline of the Saleh Bay, especially the Southern and Southwestern part, is irregular and squiggly. The coastline of the islands within the Saleh bay is also irregular. This study shows that by applying UNCLOS (1982) criteria to Saleh Bay coastline we found that 4 out of 13 studied coastline shapes did not meet bay category. Subsequently, spatial analysis indicates that Saleh Bay can be classified into eleven classes of depths with shallower parts in the south and southwestern parts of the bay and around the islands within the bay. This study presents the characteristic of Saleh Bay which is essential in providing support for coastal management, including bay management, management of marine and ecological resources, environmental services and coastal community activities.
\end{abstract}

Keywords: Saleh Bay, coastal management, spatial analysis.

\section{ABSTRAK}

Teluk Saleh adalah teluk besar di pulau Sumbawa Provinsi NTB. Teluk ini mencakup area seluas $1910 \mathrm{~km}$ persegi dengan kedalaman 0 hingga 324 meter. Garis pantai Teluk Saleh, terutama bagian selatan dan barat daya, tidak teratur dan berlekuk-lekuk. Garis pantai pulau-pulau di Teluk Saleh juga tidak teratur. Studi ini menunjukkan bahwa dengan menerapkan kriteria UNCLOS (1982) untuk kondisi pantai Teluk Saleh, ditemukan bahwa 4 dari 13 garis pantai yang diteliti tidak memenuhi kategori sebagai teluk. Selanjutnya, analisis spasial menunjukkan bahwa Teluk Saleh dapat diklasifikasikan ke dalam sebelas kelas kedalaman dengan bagian yang lebih dangkal di bagian Selatan dan Barat Daya teluk dan di sekitar pulau-pulau di dalam teluk. Studi ini menyajikan karakteristik Teluk Saleh yang penting dalam memberikan dukungan untuk pengelolaan pesisir, termasuk pengelolaan teluk, pengelolaan sumber daya ekologi laut, jasa lingkungan dan kegiatan masyarakat pesisir.

Kata kunci: Teluk Saleh, manajemen pesisir, analisis spasial.

Corresponding author:

Jl. Pasir Putih I Ancol Timur, Jakarta Utara 14430. Email: yulius.Ipsdkp@gmail.com 


\section{INTRODUCTION}

As an archipelagic state, Indonesia has a number of islands and bays, in which 341 bays have been specifically named (Ramdhan, 2012). However, naming a bay is quite different from defining it. The United Nations Convention on the Law of the Sea (UNCLOS) provides a guidance on how to define an area as a bay. Indonesia ratified the UNCLOS through Law No. 17/1985.

As a closed estuary, a bay has a strategic role as one of the ecological resources and environmental services (Ramdhan, 2012). In addition, it also serves as a center of coastal community activities, both of economic and social purposes (Anonymous, 2007). Kusumah \& Widjanarko (2007) reported the trend of numbers of community activities that are carried out in bays, including aquaculture, transportation, and infrastructures that uphold the economic-based activities. The ease of information access related with waters physical situation is certainly crucial in the comprehensive regional management of bays (Anonymous, 2004).

According to UNCLOS, a bay is defined as an indentation whose area is as large as, or larger than, that of the semi-circle whose diameter is a line drawn across the mouth of that indentation (United Nations, 1983). This identification is quite simple and straightforward. Applying the rule to Saleh Bay, however, is not simple because numerous bays exist within the Saleh Bay. This study attempts to identify bays within the Saleh Bay for bay management purposes.
Saleh Bay (Indonesian: Teluk Saleh) is administratively located in West Nusa Tenggara (Nusa Tenggara Barat/NTB) between regencies of Sumbawa and Dompu. It is semi-enclosed waters that is directly connected to Flores Sea (Mujiyanto \& Wasilun, 2006) that covers an area of $1,495 \mathrm{~km}^{2}$ with $282 \mathrm{~km}$ in length (Anonymous, 2009). Saleh Bay is also rich with coastal and marine biodiversity; thus, it is highly expected to become new potensial economic resources for the development of West Nusa Tenggara Province (Radjawane, 2006). Saleh Bay is known as the fishing ground for the traditional local community and a place for aquaculture activities such as seaweed cultivation, grouper culture in floating net cages, and pearl farming (Anonymous, 2004). Important marine biodiversity of Saleh Bay includes mangrove ecosystem, corals, and reef fishes (Satria \& Mujiyanto, 2011). Some small islands, including Dangar Rea Island, Liang Island, Ngali Island, and Rak Island (Ismunarti \& Rochaddi, 2013) are found in Saleh Bay.

The topography of the seabed at Sumbawa district coastal areas is sloping and it is steadily steep toward the waters of Dompu district (Ismunarti \& Rochaddi, 2013). Depths of the bay waters were estimated from Bathymetric DEM (Digital Elevation Model) and were used for the delineation of boundaries, marine scientific study, aquaculture development, marine tourism, safety in shipping, exploration of marine and seabed resources, coastal engineering, ocean modeling, determination of navigational channel and ports, aquaculture, and so on (Yulius et al., 2011).

This study is aimed at verifying bays and bathymetry of Saleh Bay regarding UNCLOS criteria by using Geographic Information System (GIS). The

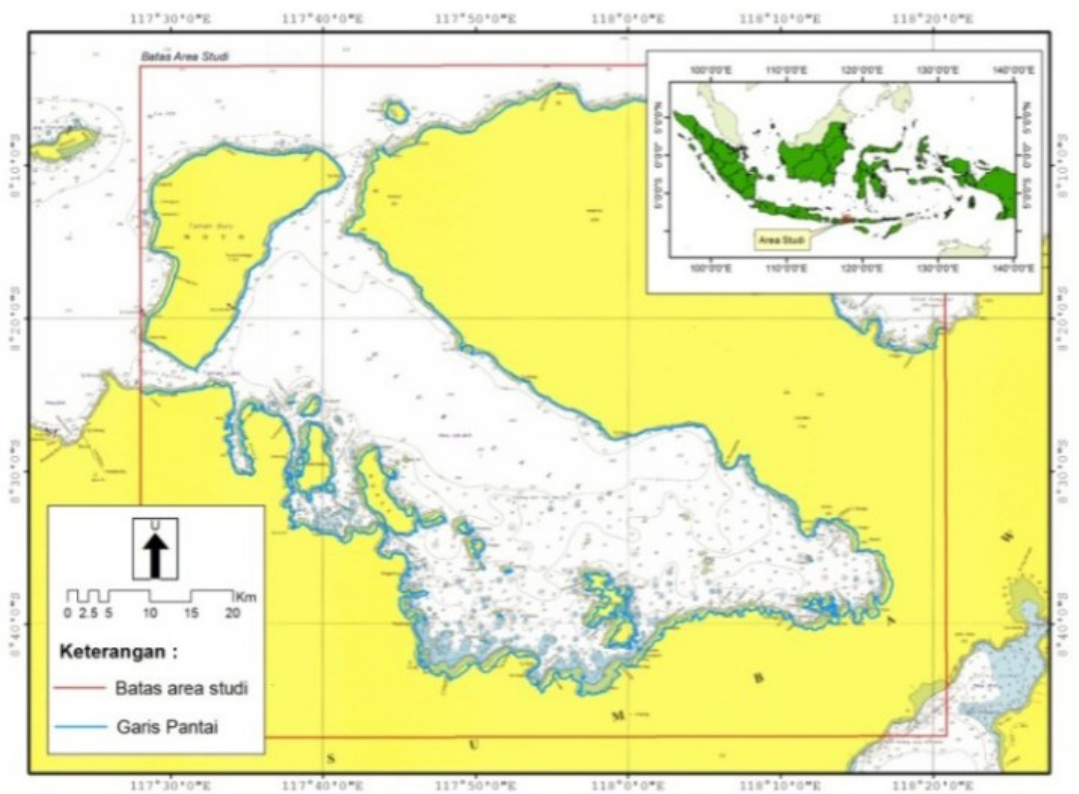

Figure 1. Study Area of Saleh Bay, West Nusa Tenggara Province. 
results of this research are expected to be useful to support the utilization of economic zone of Saleh Bay for marine tourism, safety in shipping, determination of navigational channel and ports, aquaculture, and others.

\section{METHODOLOGY}

\section{Study Area}

The study area are in Saleh Bay, West Nusa Tenggara (Figure. 1).

\section{UNCLOS Criteria for the Determination of a Bay}

In the article 10 of UNCLOS, a region is called a bay if a well-marked indentation whose penetration is in such proportion to the width of its mouth as to contain land-locked waters and constitute more than a mere curvature of the coast. An indentation shall not, however, be regarded as a bay unless its area is as large as, or larger than, that of the semi-circle whose diameter is a line drawn across the mouth of that indentation (Figure 2). If an indentation has more than one mouth, the diameter of these semicircle is a line of the sum total of the lengths of the lines across the different mouths (UNCLOS,1983). A bay also has a proviso that if the distance between low water-marked at the natural entrance points of a bay does not exceed 24 nautical miles, the closing lines may be drawn between these two low-water lines and closed waters and therefore considered as in-land waters. If the distance exceeds 24 nautical miles, then a straight baseline drawn 24 nautical miles in length in the bay such that the closing of a maximum area of water that may be achieved by the long line (Figure 3) (Yulius \& Salim, 2015).

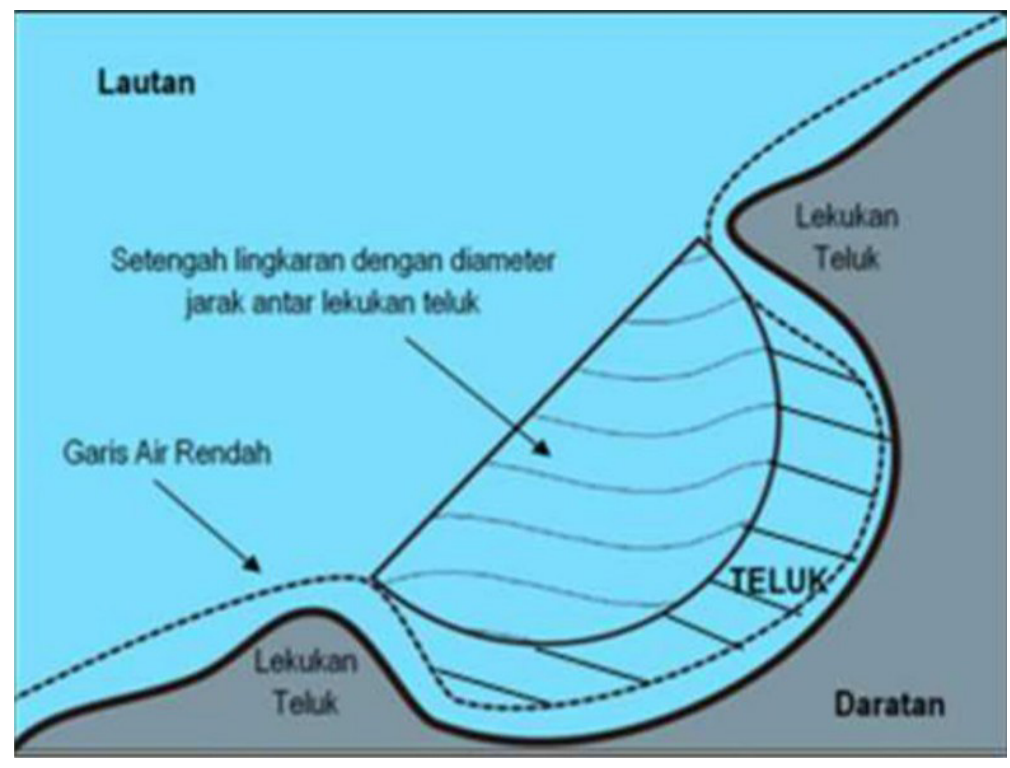

Figure 2. Criteria of Bay based on UNCLOS (Source: United Nations, 1983 in Ramdhan, 2012).
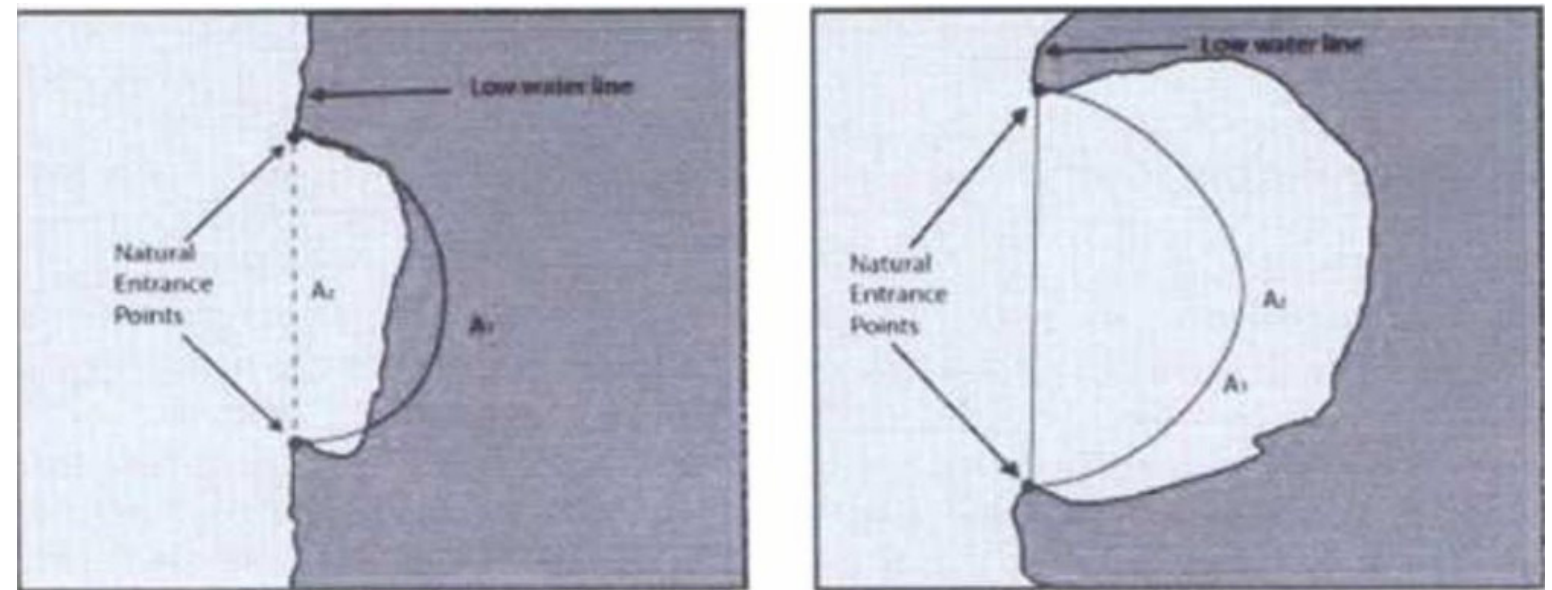

Figure 3. Article 10, Verse 4 UNCLOS: A bay as an inlad water, not included as a bay (left), included as a bay (right) (source: IHO, 2006 in Yulius \& Salim, 2015). 
Tabel 1. Correlation between SSTA and CPUE of sardine (Sardinella lemuru) at the extreme periods.

\begin{tabular}{|c|c|c|c|c|c|}
\hline No & Data & Scale/Resolution & Edition & Sheet & Format \\
\hline 1 & Pushidrosal Map & $1: 200,000$ & 2006 & 294 & JPEG, raster \\
\hline 2 & Landsat 8 & 30 meters & 2014 & P116/R66 & Geo Tiff, raster \\
\hline
\end{tabular}

\section{Analysis}

This analysis was based on Pushidrosal Map sheet 294 of Sumbawa Island (Middle part) - Nusa Tenggara scale of 1: 200,000 , which is shown in Table 1.

The coordinate systems of the data were registered by using global mapper software to make the coordinate system similar to WGS 84/UTM zone 47S (Yulius \& Salim, H.L, 2015). Furthermore, the identification and delineation of the bay area on the map were carried out. Analysis to determine whether an indentation is a bay or not was performed in accordance to the UNCLOS, by using the measurement of total bay area $(\mathrm{L})$ produced from the delineation of the bay boundaries and the radius of the mouth obtained from the closing line as semi-circle diameter

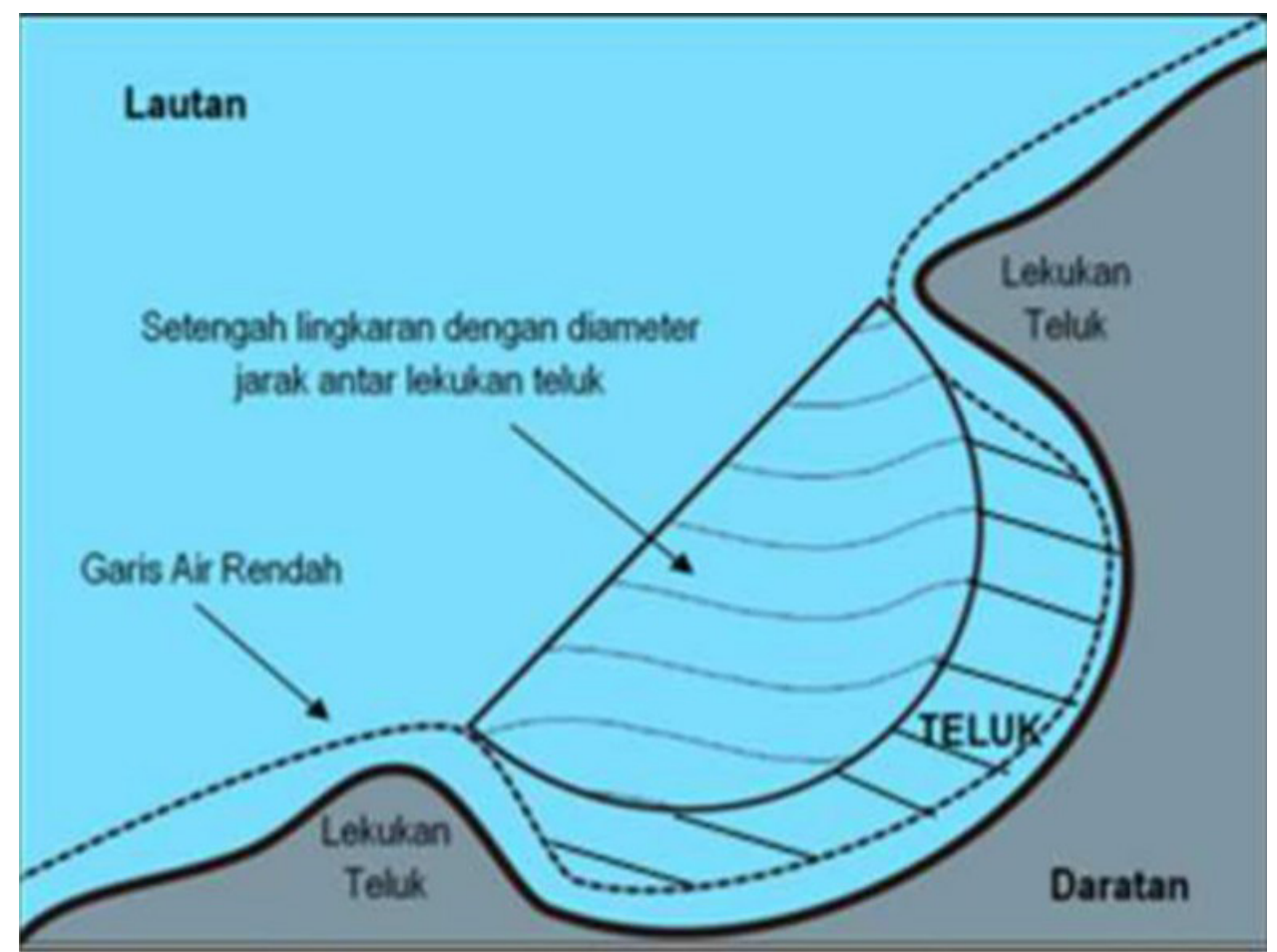

Figure 2. Criteria of Bay based on UNCLOS (Source: United Nations, 1983 in Ramdhan, 2012).
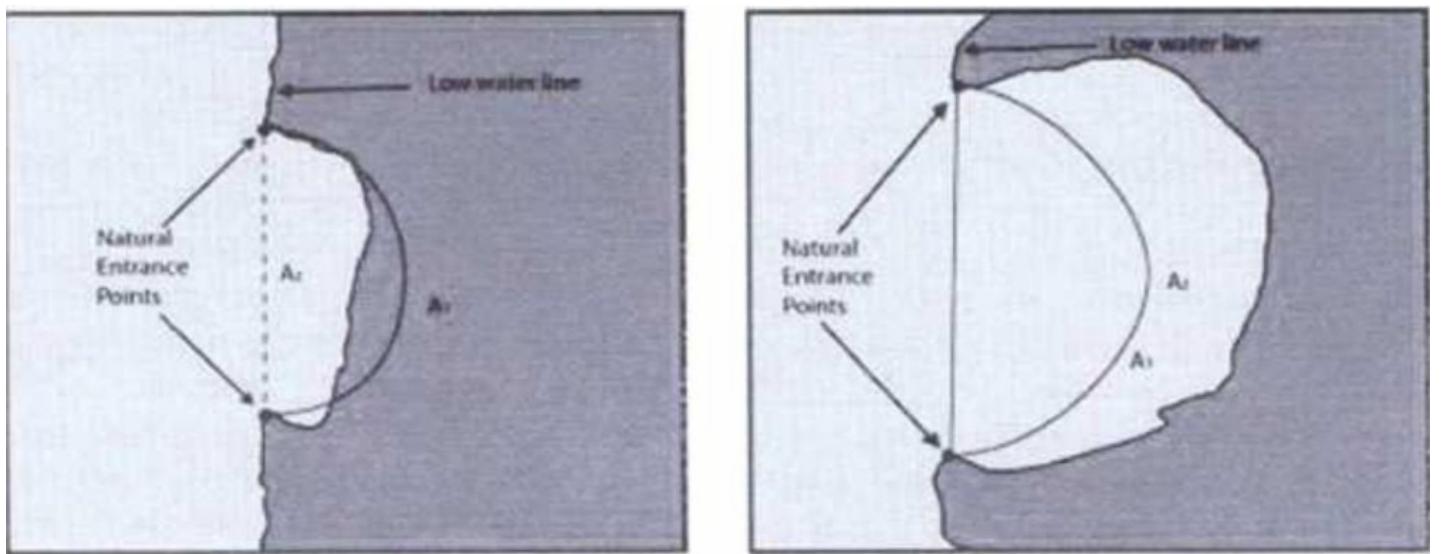

Figure 3. CArticle 10, Verse 4 UNCLOS: A bay as an inland water, not included as a bay (left), included as a bay (right). (source: IHO, 2006 in Yulius and Salim, 2015). 


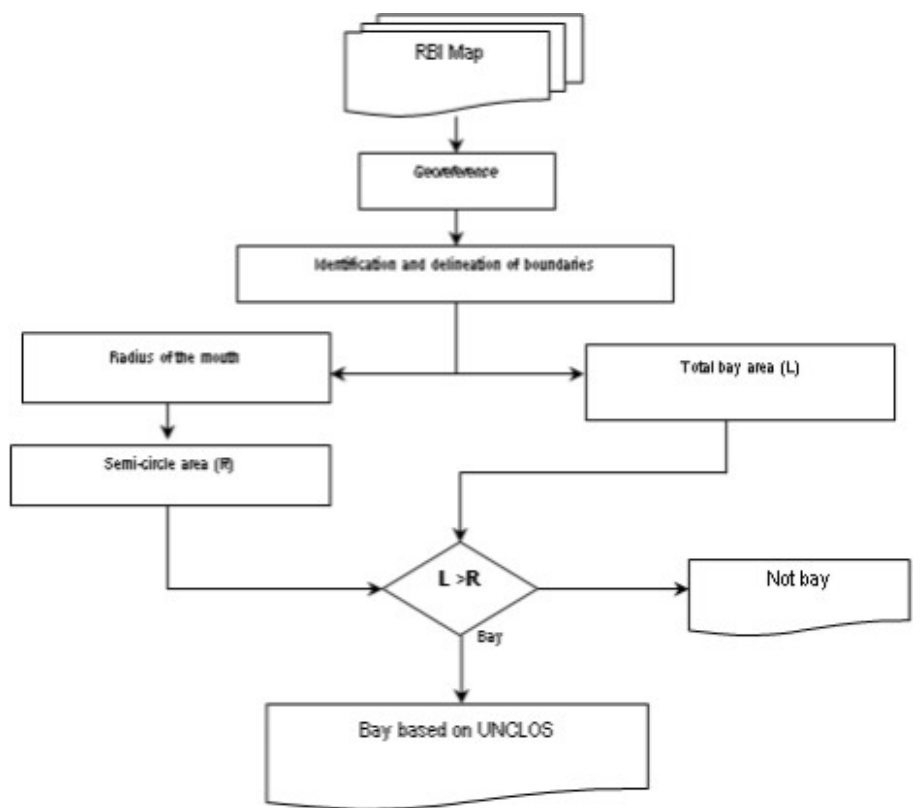

Figure 4. Flow diagram of the analysis to determine a bay based on UNCLOS.

(Figure 4).

\section{Bathymetry by using GIS Method}

Bathymetric Digital Elevation Model (DEM) was made by employing the tool in ArcGIS software, namely topo to raster tools. These tools are similar with other tools in creating DEM (raster) data that use interpolation techniques, but it has distinctive benefit that the input can be more than one specific data. However, these tools can only be used to produce elevation raster or DEM (Figure 5).
The sources of elevation data are diverse. Among the elevation data are depths (point) and contour (line). These tools can include the elevation data simultaneously. In addition, the spatial data of morphological objects such as rivers, coastlines, lakes, cliffs, and sinks can also be included and examined to extract DEM. Polygon layer such as administrative boundary and watershed area can be used as an input to limit the interpolated data and to produce the DEM data precisely based on the expected area. Figure 6 shows the data used to build bathymetric DEM, namely the depths (point) and contour (line). In addition, the

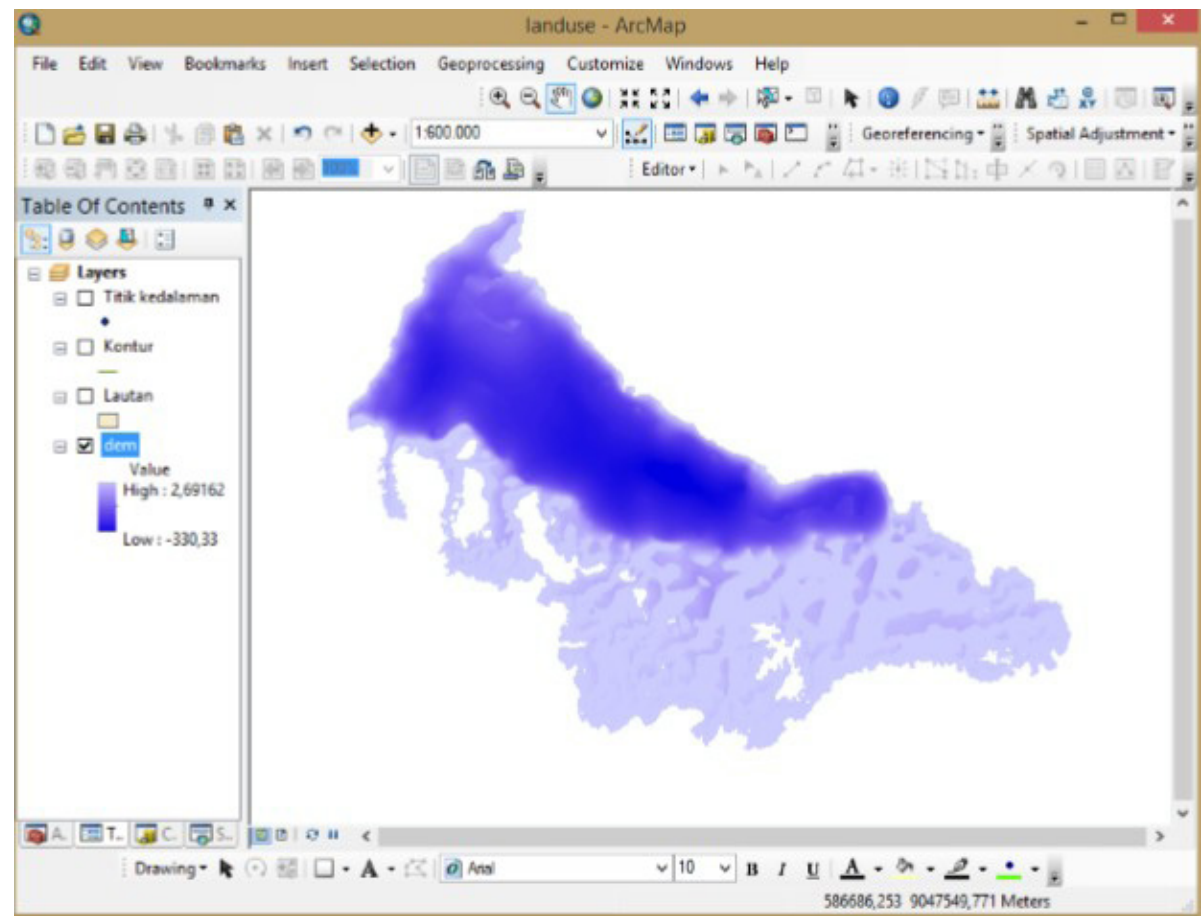

Figure 5. Result of topo to raster interpolation technique with pixel resolution of $25 \mathrm{~m}$. 


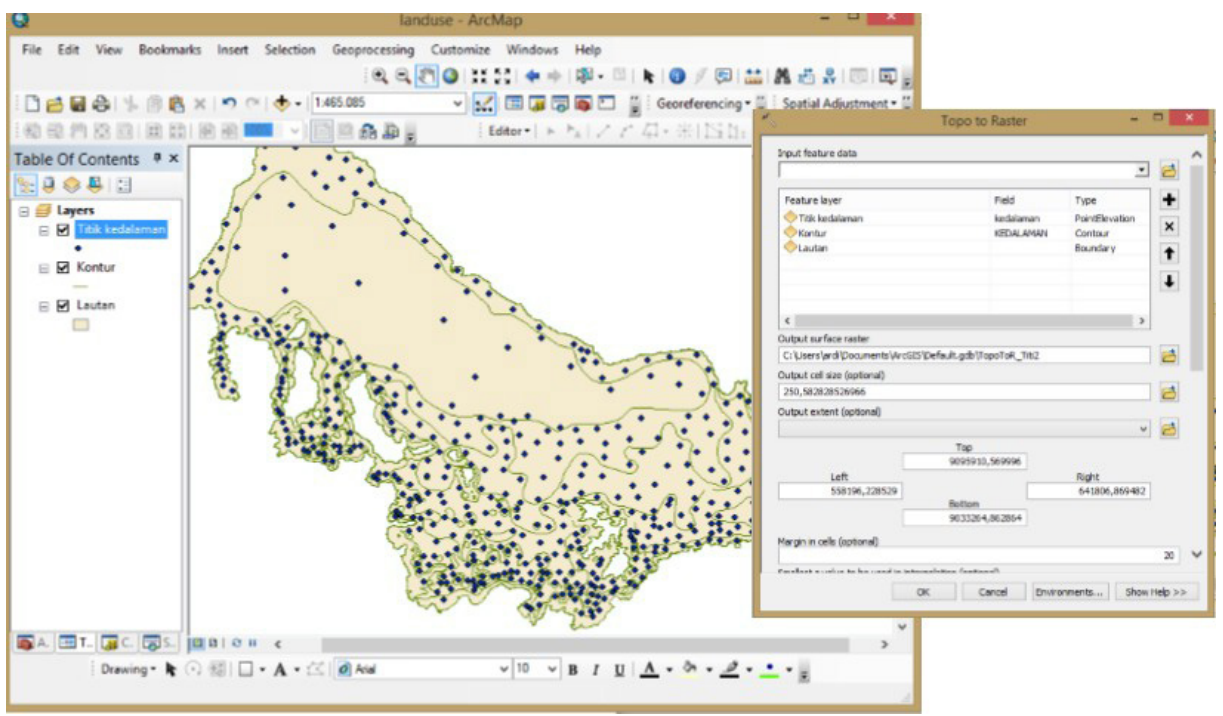

Figure 6. Data of Bathymetric DEM: depths (points) and contour (lines).

ocean polygon was used as interpolation boundary.

\section{RESULTS AND DISCUSSION}

\section{Identification of a Bay}

The Bays in the study area were identified based on the Pushidrosal map and Landsat 8. The studied bays are located within the Saleh Bay (Figure 7), including Praya Bay, Tarata Bay and Taru Bay, as well as the bays in Rakit island such as Katumpang Bay, Dalam Bay, Sakeka Bay, and Tambora Bay. Moreover, Santong Bay, Kundu Bay, Ndango Bay, Bangkolua Bay, Napa Bay, and Kempo Bay in the Southern part of Saleh Bay were also included in the analysis.
Calculation by using GIS software indicates that the length of the coastline of Saleh Bay is $127.7 \mathrm{~km}$, the closing lines is $11.1 \mathrm{~km}$, and the total area is $2,099.69$ $\mathrm{km}^{2}$ with the depths up to 324 meters. The area was assessed with coastline parameters obtained from the $\mathrm{RBI}$ map and it was assumed that the coastline is the low-water line for the study area. The aforementioned bays (Figure 8 ) were analyzed by applying UNCLOS criteria and the results are shown in Table 2.

Table 2 summarizes the results by applying UNCLOS criteria to bays of Saleh Bay; the bays that do not meet the UNCLOS criteria are Tarata Bay, Katumpang Bay, Kundu Bay, and Bangkolua Bay.

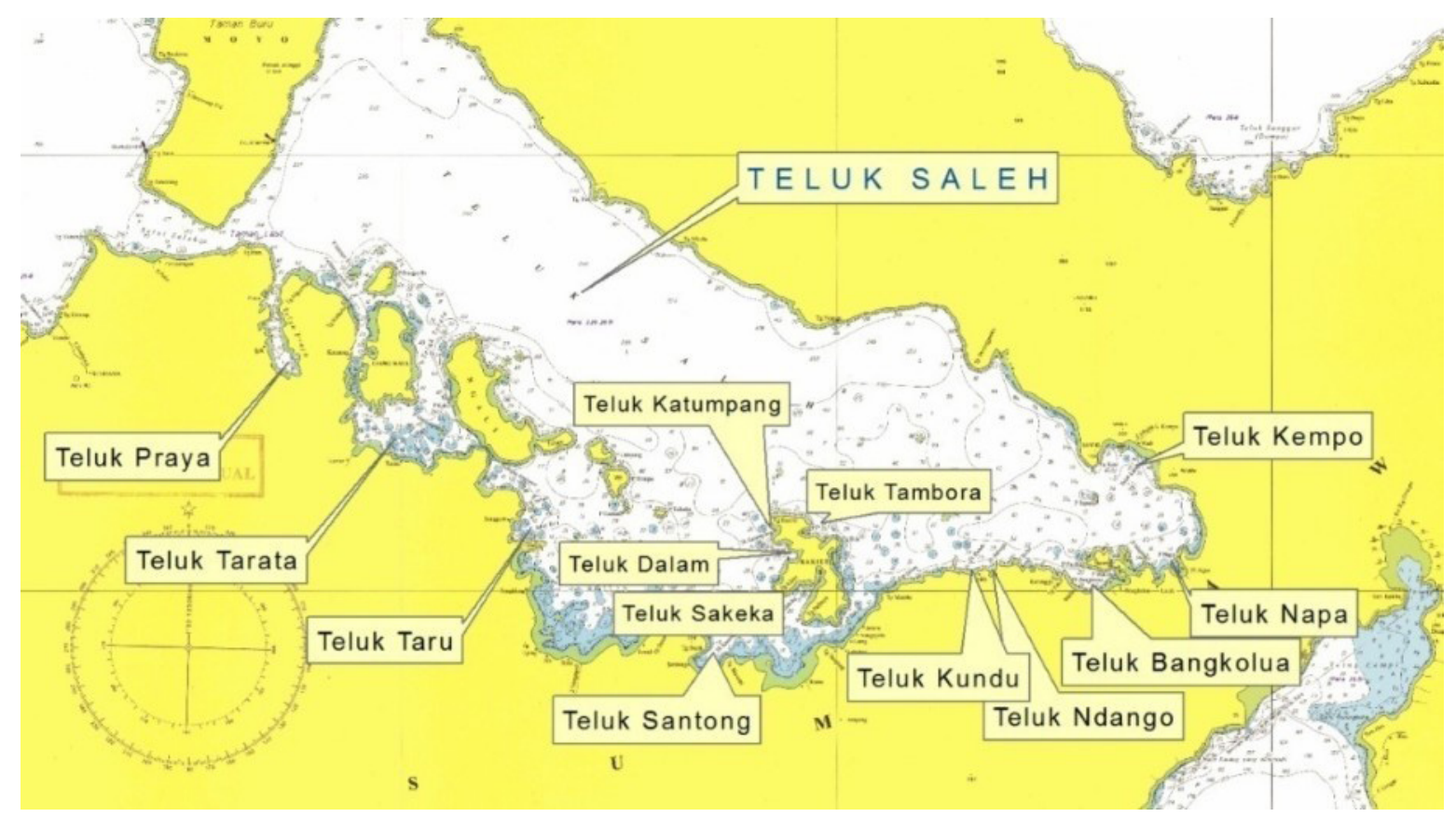

Figure 7. Bays in the studied area. 


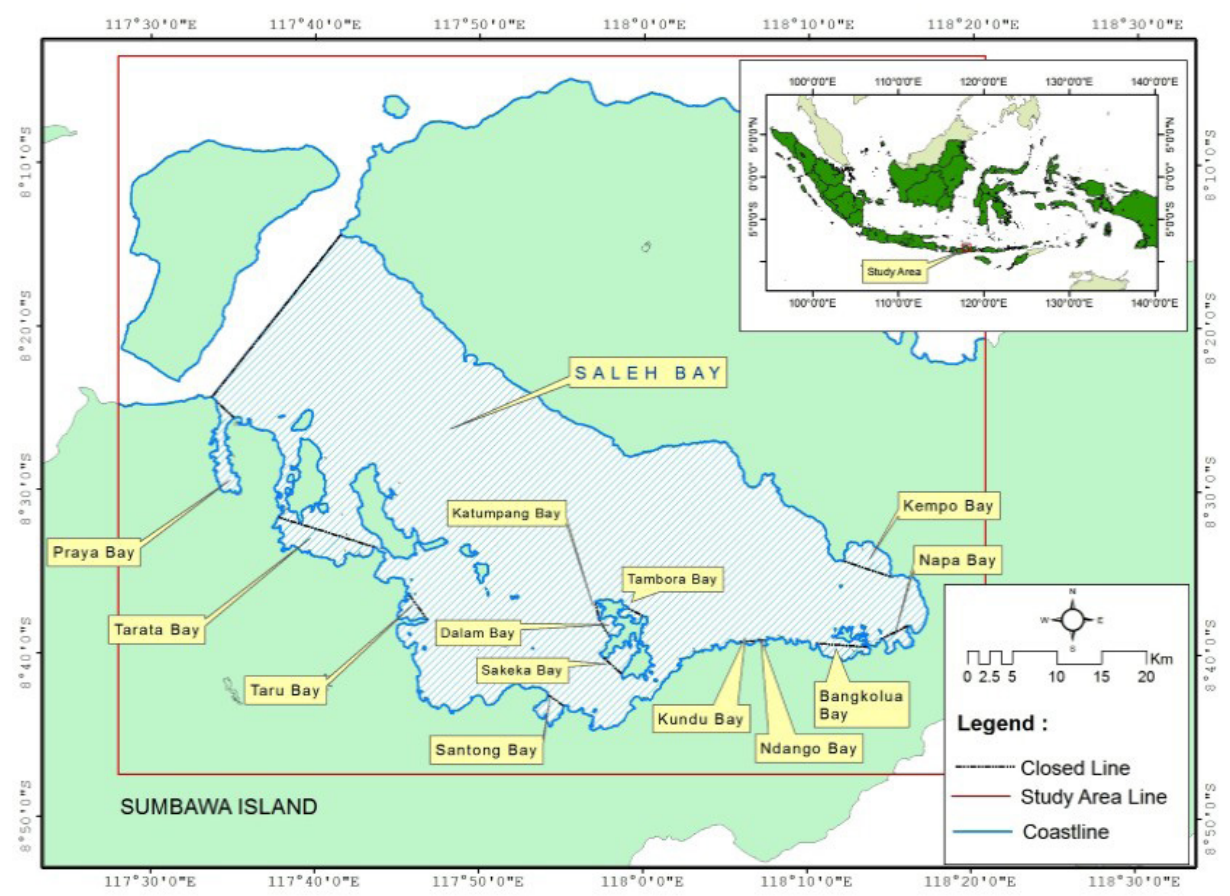

Figure 8. Coastline and closed lines of Saleh Bay and the bays within the Saleh Bay that were used as parameters to determine whether an area is a bay.

Spatial analysis of Saleh Bay indicates the areal extend of specific range of depths of the bay area (Yulius et. al., 2011), as shown in Table 3. Visual representation of the range of depths indicated in Table 3 is shown in Figure 9.

\section{CONCLUSION}

The study of Saleh Bay coastline confirmed that 10 (ten) of the coastline indentation were bays and the other 4 (four) were not bays according to UNCLOS criteria. The coastline of Saleh Bay was $127.7 \mathrm{~km}$, the closing line was $11.1 \mathrm{~km}$, and the total area was $2,099.69 \mathrm{~km}^{2}$ with the maximum depths of 324 meters. Spatial analysis of the bathymetry of the studied area shows that a large portion of deep area with depths of more than 100 meters was located in the Northern part of the Saleh Bay.

\section{ACKOWLEDGEMENTS}

This survey research is funded by APBN DIPA for RDCMCR fiscal year 2014. Revisit and reanalysis data

Tabel 2.

Parameters to determine bays

\begin{tabular}{llllll}
\hline No & Name of Bay & $\begin{array}{l}\text { Line diameter } \\
(\mathbf{m})\end{array}$ & $\begin{array}{l}\text { Semi-circle A } \\
\text { rea }=\mathbf{R}\left(\mathbf{m}^{\mathbf{2}}\right)\end{array}$ & Area $=\mathbf{L} \mathbf{( m}^{\mathbf{2})}$ & $\mathbf{L}>\mathbf{R}$ \\
\hline 1 & Praya & $2,655.01$ & $2,766,768.43$ & $15,471,518.45$ & Bay \\
2 & Tarata & $11,257.92$ & $49,745,728.42$ & $26,780,650.27$ & Not bay \\
3 & Taru & $3,300.64$ & $4,275,971.12$ & $5,141,482.50$ & Bay \\
4 & Dalam & $2,271.67$ & $2,025,485.61$ & $3,468,455.50$ & Bay \\
5 & Sakeka & $2,687.88$ & $2,835,690.46$ & $7,639,550.91$ & Bay \\
6 & Santong & $2,200.50$ & $1,900,560.71$ & $6,216,453.50$ & Bay \\
7 & Katumpang & $1,738.16$ & $1,185,821.35$ & $962,377.37$ & Not bay \\
8 & Tambora & $1,833.00$ & $1,318,751.54$ & $2,235,278.43$ & Bay \\
9 & Kundu & $1,571.48$ & $969,303.93$ & $379,901.07$ & Not bay \\
10 & Ndango & 786.95 & $243,073.32$ & $377,018.00$ & Bay \\
11 & Bangkolua & $5,594.13$ & $12,283,022.25$ & $6,989,491.85$ & Not bay \\
12 & Napa & $3,319.07$ & $4,323,880.49$ & $5,259,584.05$ & Bay \\
13 & Kempo & $5,625.36$ & $12,420,525.16$ & $13,121,694.67$ & Bay \\
14 & SALEH & $23,357.01$ & $214,128,385.51$ & $2,030,687,506.05$ Bay \\
\hline
\end{tabular}


Tabel 3.

Range of Bathymetry and its areal extend in the studied area.

\begin{tabular}{llll}
\hline No & Bathymetry $(\mathbf{m})$ & Area $\left(\mathbf{k m}^{\mathbf{2}}\right)$ & Percentage $\mathbf{( \% )}$ \\
\hline 1 & $0-10$ & 294.27 & 14.01 \\
2 & $10-20$ & 205.45 & 9.78 \\
3 & $20-30$ & 259.45 & 12.36 \\
4 & $30-40$ & 146.25 & 6.97 \\
5 & $40-50$ & 137.83 & 6.56 \\
6 & $50-75$ & 148.19 & 7.06 \\
7 & $75-100$ & 57.08 & 2.72 \\
8 & $100-150$ & 73.78 & 3.49 \\
9 & $150-200$ & 109.46 & 5.21 \\
10 & $200-300$ & 533.42 & 25.40 \\
11 & $>300$ & 134.89 & 6.42 \\
\hline & Total & $1,910.07$ & 99.98 \\
\hline
\end{tabular}

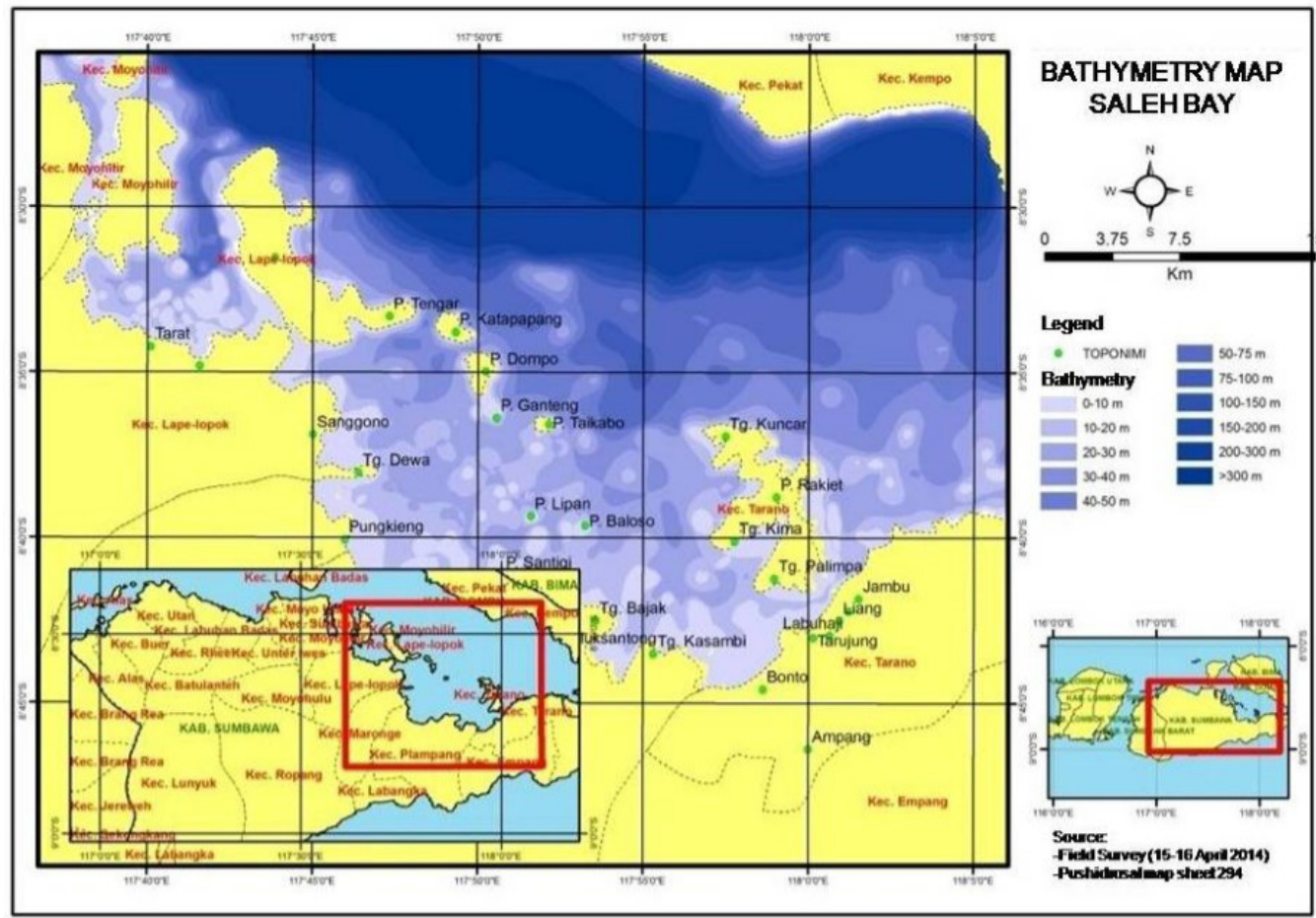

Figure 9. Saleh Bay Bathymetry.

have been conducted during 2017 .

\section{REFFERENCE}

Anonymous, (2004). Daya dukung kelautan dan perikanan Selat Sunda, Teluk Tomini, Teluk Saleh dan Teluk Ekas. Badan Riset Kelautan dan Perikanan. Jakarta. p. 122.

Anonymous, (2007). Buku panduan survei toponim teluk dan tanjung di Indonesia. Jakarta. p. 1-63.

Anonymous, (2009). Membangunkan "raksasa" di Teluk Saleh, menuju kawasan ekonomi khusus kelautan dan perikanan. Cited inhttp://www. sumbawakab.go.id/.[3 June 2015]
Ismunarti, D.H. \& Rochaddi, B. (2013). Kajian pola arus di perairan Nusa Tenggara Barat dan simulasinya menggunakan pendekatan model matematik. Buletin Oseanografi Marina. Juli 2013. Volume 2. p. $1-11$

Manan, B. (2006). Konvensi ketatanegaraan. Fakultas Hukum. UII Press. Yogyakarta.

Mujiyanto. \& Wasilun, (2006). Kondisi oseanografi di perairan Teluk Saleh, Nusa Tenggara Barat. Prosiding Seminar Nasional Ikan IV. Organized by LRPSI, LIPI, and MII. p. 217-223.

Kadmon, N. (2004). Toponymy and Geopolitics: The Political Use - and Misuse - of Geographical 
Names. The Cartographic Journal. 2004. doi:10.1179/000870404X12897.

Kusumah, G. \& Widjanarko, E. (2007). Identifikasi teluk dan tanjung di Teluk Bungus berdasarkan kaidah toponimi maritim. Jurnal Segara: 3(2):105-111.

Radjawane, I.M, Herdiani, Y., Pranowo, W.S., Husrin, S. \& Supangat, A. (2006). Sirkulasi arus vertikal di perairan Teluk Saleh Sumbawa, Nusa Tenggara Barat. Jurnal Segara, Vol 2 (1): 10-15.

Ramdhan, M. (2012). Kriteria penentuan teluk menurut United Nation Conventions on the LAW of the SEA - Studi Kasus Wilayah Bungus Teluk Kabung Kota Padang. Jurnal Ilmiah Geomatika: 18 (2):37-46.

Satria, H. \& Mujiyanto, (2011). Struktur komunitas ikan karang di lokasi terumbu karang buatan di perairan Teluk Saleh, Nusa Tenggara Barat. Prosiding Forum Nasional Pemacuan Stok Ikan III: Kestabilan Produksi Ikan. Organized by BP2KSI, FPIK, UNPAD, LIPI, and MII. 18 October 2011. Hal. KSI-10.p. 1-16.

United Nations, (1983), The Law of the Sea - UN Convention on the Law of the Sea 1982, UN Publication No. E.83.V.5. New York, NY.1-194pp.

United Nations Conference on the Standardization of Geographical Names, London, 10-31 May 1972. 1974. New York: United Nations. Dept. of Economic and Social Affairs, p. 68.

Yulius, Prihatno, H., \& Suhelmi, I.R. (2011). Pola spasial kedalaman perairan di Teluk Bungus, Kota Padang. Prosiding Pertemuan IImiah Nasional Tahunan VII ISOI 2010:205-212.

Yulius \& Salim, H.L. (2015). Identification and Spatial Pattern of Kao Bay Bathymetry. Forum Geografi, Vol. 29 (1) July 2015: 23-30. 
